\title{
Suomalaisten tutkijoiden sosiaalisen median käyttö: sosiaalisen median merkitys työssä, tiedonhankinnassa ja tieteellisen tiedon jakamisessa
}

\author{
Elina Late \\ Tampereen yliopisto \\ elina.late@uta.fi \\ https://orcid.org/0000-0002-3232-1365 \\ Sanna Kumpulainen \\ Tampereen yliopisto \\ sanna.kumpulainen@uta.fi \\ https://orcid.org/0000-0002-7016-257X
}

Sanna Talja

Tampereen yliopisto

sanna.k.talja@uta.fi

Lisa Christian

University of Tennessee

lchrist2@utk.edu

https://orcid.org/0000-0001-7347-1442

Carol Tenopir

University of Tennessee

ctenopir@utk.edu

http://orcid.org/0000-0002-9056-8251 


\begin{abstract}
The use of social media in scholarly communication has grown in recent years, and consequently, scholars' uses of social media has gained importance as a research topic. The aim of this article is to shed light on the role of social media in scholars' work. The research presents findings from a survey $(\mathrm{N}=528)$ conducted in Finland in late 2016. There exists no prior research on the role and uses social media among Finnish scholars. This research specifically focuses on the perceived role of social media in information seeking and sharing. We also study the differences between disciplines, age groups, and positions. Results show that scholars do not perceive social media as being central for their or information seeking and sharing, and that social media services are not replacing traditional publishing forums. Scholars do appreciate the social media services intended and developed for academic use, and find them as having value for their work than general social media services. However, according to our results, social media services have a marginal role in scholars' information seeking and scholars infrequently share their readings in social media platforms. Some disciplinary differences existed, but there was no connection between scholars' age or position and the role of social media. Our study shows that the role of social media in academic work and scholarly communication is still rather small. Further research is needed to find out what are the reasons for scholars lack of interest towards social media.
\end{abstract}

Asiasanat: tutkimus; tutkimustyö; tutkija; sosiaalinen media; tiedonhankinta

VERTAISARVIOITU

KOLLEGIALT GRANSKAD

PEER-REVIEWED
www.tsv.fi/tunnus

Sosiaalisesta mediasta on tullut merkittävä viestintäkanava nykypäivän yhteiskunnassa. Akateeminen maailma ei ole jäänyt sosiaalisen median ulkopuolelle vaan päinvastoin, tutkimustietoa jaetaan aktiivisesti erilaisissa sosiaalisen median palveluissa. Sosiaalisen median palvelut voidaan märitellä seuraavasti; palvelut mahdollistavat käyttäjälle 1) julkisen tai osittain julkisen profiilin luomisen, 2) yhteyksien luomisen toisiin järjestelmän käyttäjiin ja 3) omien ja toisten luomien yhteyksien tarkastelemisen järjestelmän sisällä (Boyd \& Ellison, 2007, s. 211).

Osa sosiaalisen median palveluista on rakennettu erityisesti tieteen ja tutkijoiden tarpeisiin. Näitä ovat esimerkiksi ResearchGate ja Academic.edu, joissa tutkijat voivat luoda yhteyksiä sekä esitellä ja jakaa julkaisujaan. Tunnettuja palveluja ovat myös Mendeley ja Zotero, jotka ovat kehitetty ensisijaisesti viitteidenhallintaan, mutta jotka pitävät sisällään myös sosiaalisen median elementtejä, kuten mahdollisuuden sosiaalisten yhteyksien ja ryhmien luomiseen. Näitä palveluja kutsutaankin tutkimuksen tai akateemisiksi sosiaalisen median palveluiksi (academic social networking sites, ASNS). Vaikka tiettyjä palveluja on luotu nimenomaan tutkijoiden käyttöön, on yleisten sosiaalisen median palvelujen, kuten Facebookin, käyttö tavanomaista myös tutkijoiden piirissä.

Gu ja Widen-Wulff (2011) ovat esittäneet tutkimuksen sosiaalisen median palvelujen jakaantuvan kahdeksaan eri luokkaan: blogit, mikroblogit, uutuusseuranta (RSS), wikit, tunnisteet (tägit), sosiaaliset verkostot, multimedian jako, ja online dokumentit. Usein myös Google Scholar luetaan sosiaalisen median 
palveluksi, sillä sinne voi luoda oman profilin. Google Scholar ei kuitenkaan tarjoa mahdollisuutta viestintään profiilien välillä. Sosiaalinen media onkin määritelty eri tavoin eri tutkimuksissa ja määritelmä muokkautuu uusien palvelujen myötä (Sugimoto, Work, Larivière, \& Haustein, 2017). Sosiaalisen median palvelujen avulla tutkijat voivat jakaa aineistoja, vaihtaa mielipiteitä ja ajatuksia, seurata toistensa tutkimusta, pysyä ajan tasalla tutkimuksen kehityksessä ja rakentaa ammatillisia verkostoja (Krause, 2012).

Akateemiset sosiaalisen median palvelut ja tutkijoiden sosiaalisen median käyttö ovat herättäneet kiinnostusta viimeisten vuosien aikana (Sugimoto ym., 2017). Kansainvälisesti tutkimusta on tehty melko paljon, kun taas Suomessa sen sijaan tutkimus on toistaiseksi ollut vähäistä (esim. Katvala \& Kortelainen, 2012). Tässä artikkelissa esitellään Suomessa loppuvuodesta 2016 tehdyn kyselytutkimuksen tuloksia. Tutkimuksessa tarkastellaan sosiaalisen median roolia tutkijan työssä ja se tuottaa uutta tietoa tutkijoiden sosiaalisen median käytöstä. Tätä tietoa voidaan hyödyntää esimerkiksi tutkijapalveluiden suunnittelussa. Tutkimuskysymykset ovat:

1. Miten tärkeiksi tutkijat kokevat eri sosiaalisen median palvelut työssään?

2. Miten tutkijan edustama tieteenala, ammatillinen asema ja ikä vaikuttavat sosiaalisen median rooliin tutkijan työssä?

3. Mikä rooli sosiaalisella medialla on osana tutkijoiden tiedonhankintaa?

4. Miten usein tutkijat jakavat lukemiaan julkaisuja sosiaalisessa mediassa?

Artikkelin rakenne on seuraava. Ensin esittelemme aiempaa tutkijoiden sosiaalisen median käyttöä käsittelevää tutkimusta. Tämän jälkeen esittelemme tutkimusaineiston ja sen analysoinnin. Tutkimustuloksia esittelevä luku on jaettu kolmeen alalukuun, joissa käsitellään sosiaalisen median merkitystä tutkijoiden työssä, sosiaalisen median roolia tiedonhankinnassa sekä julkaisujen jakamista sosiaalisessa mediassa. Johtopäätöksissä vastataan tutkimuskysymyksiin ja ehdotetaan jatkotutkimuksen aiheita.

\section{Aiempi tutkimus}

\section{Tutkijoiden sosiaalisen median käyttö}

Sosiaalisessa mediassa ja verkossa näkyvillä olo ollaan nähty tärkeäksi tutkimustiedon sosiaalisen vaikuttavuuden ja tutkijan maineen rakentumisen kannalta (Jordan, 2014; Nicholas ym., 2015). Useissa tutkimuksissa on kuitenkin raportoitu, että tutkijat ovat ottaneet sosiaalisen median palveluita hitaasti käyttöönsä (esim. Haustein ym., 2014; Mas-Bleda, Thelwall, Kousha, \& Aguillo, 2014). 
Sosiaalisen median asemaa ovat korostaneet uudet metriikat, joilla pyritän mittamaan tutkimuksen vaikuttavuutta. Altmetriikan keinoin pyritään mittamaan tutkimuksen sosiaalista vaikuttavuutta laskemalla tutkimuksen näkyvyyttä mm. sosiaalisessa mediassa (Weller, 2015). Kuitenkaan tieteellinen ja sosiaalinen vaikuttavuus eivät välttämättä ole irrallaan toisistaan. Esimerkiksi Eysenbach (2011) ja Thelwall (2018) osoittivat tutkimuksissaan, että paljon sosiaalisessa mediassa huomiota (twiittauksia ja lukijoita Mendeleyssä) saavat artikkelit saavat todennäköisesti myös enemmän viittauksia tieteellisissä julkaisuissa.

Kaikki eivät kuitenkaan ole vakuuttuneet esimerkiksi altmetriikan kyvystä mitata tutkimuksen sosiaalista vaikuttavuutta tai koe, että tutkijoiden olisi välttämätöntä olla läsnä sosiaalisessa mediassa (Sugimoto ym., 2017). Greifeneder kumppaneineen (2017) argumentoi, että todellisuudessa läsnäolo sosiaalisessa mediassa voi olla jopa haitallista tutkijalle ja että monet tutkijat tietoisesti välttelevät sosiaalista mediaa. Sosiaalisen median päivittäminen ja seuraaminen vie tutkijoilta aikaa ja tämän ajan voidaan kokea olevan pois varsinaiselta työltä. Mas-Bleda kumppaneineen (2014) taas uskoo, että kyseessä on enemminkin teknologian kehityksestä tipahtaminen, ei niinkään tietoinen valinta.

Ollaan sosiaalisesta mediasta mitä mieltä hyvänsä, se on kuitenkin merkittävä osa tämän päivän viestintää ja monet tutkijat ovat myös omaksuneet sosiaalisen median osaksi työtään. Tenopir kollegoineen (2013) tutki tutkijoiden sosiaalisen median käyttöä ja sisältöjen luomista Britanniassa. Kyselytutkimus osoitti, että suurin osa tutkijoista hyödyntää ainakin jotakin sosiaalisen median palvelua. Sisältöjen luominen sosiaaliseen mediaan oli kuitenkin satunnaista. Tutkimus myös osoitti, ettei ainakaan viisi vuotta sitten sosiaalinen media ollut korvaamassa perinteisiä tieteellisen tiedon foorumeita, kuten tieteellisiä lehtiä ja kirjoja. Itse asiassa tutkimuksessa havaittiin, että aktiiviset sosiaalisen median hyödyntäjät olivat myös aktiivisia perinteisten julkaisufoorumien seuraajia ja lukivat keskimääräistä enemmän esimerkiksi tieteellisiä artikkeleita.

Myös Grudz ja Goertzen (2013) tutkivat kyselylomakkeella tutkijoiden sosiaalisen median käyttöä ja palveluiden koettuja hyötyjä. Tutkimuksen mukaan yleisimmät sosiaalisen median hyödyt tutkijoille olivat: ajan tasalla pysyminen, toisten tutkimuksen seuraaminen, uusien ideoiden ja julkaisujen löytäminen, oman tutkimuksen markkinointi sekä uusien kontaktien luominen. Läsnäolo sosiaalisessa mediassa voi kuitenkin hämärtää työn ja vapaa-ajan rajaa (Gruzd, 2012). Osittain tästä syystä osa tutkijoista keskittyykin akateemisen sosiaalisen median palveluissa ainoastaan suoraan tutkimukseen ja työhön liittyviin toimintoihin ja sivuuttavat varsinaiset sosiaaliset toiminnot, kuten "ystävystymisen" (Jeng, He, \& Jiang, 2015). Sosiaalisen median palvelut ovat kiinnostavia kanavia jakaa tietoa esimerkiksi omista ja muiden julkaisuista. Tiedon jakamisen onkin ennustettu kasvavan tulevaisuudessa (Tenopir ym., 2017). 


\section{Sosiaalinen media ja tiedonhankinta}

Tutkijat voivat jakaa sosiaalisessa mediassa julkaisujaan ja ajatuksiaan. Se, että julkaisuja on tarjolla, ei kuitenkaan suoraan kerro siitä miten niitä haetaan ja käytetään. van Noorden (2014) tutki erilaisten sosiaalisen median palveluiden suosiota niiden käyttötarkoituksen mukaan ja havaitsi, että eri palveluilla on erilainen luonne ja tarkoitus ja niitä myös käytetään puhtaasti eri tarkoituksiin. Samanlaisia tuloksia saivat Haustein ja kumppanit (2014). Heidän mukaansa ResearchGatea ja Academia.edua käytetään artikkelien tallennukseen ja lataamiseen ja Google Scholaria puolestaan sitaattien tarkastukseen. Yksi käyttötapa on tiedonhaku. Kaikkein tunnetuin ja käytetyin sosiaalisen median palvelu oli van Noordenin (2014) mukaan Google Scholar, mutta tiedonhakuun käytettiin myös akateemisia verkostoitumissivustoja (ResearchGate ja Academia.edu) sekä sosiaalista viittaustyökalua (Mendeley). Ajankohtaisten tutkimusteemojen seuraamiseen sekä konferenssiviestintään sopi parhaiten Twitter, joka kyselyn mukaan näyttäytyi kaikkein keskeisimpänä tutkimustiedon lähteenä (van Noorden, 2014).

Sosiaalisen median palvelut ovat kaikki paljon käytettyjä tiedonhaun kanavia Nicholasin ym. (2017) mukaan. Tiedonhaku on siirtynyt yhä enemmän mobiilialustoille kuten matkapuhelimiin, mutta varsinainen lukeminen tehdään edelleen toisaalla. Kuitenkin perinteiset journaaliartikkelit olivat heidän mukaansa kaikkein tärkein tieteellisen tiedon lähde, ja samaan päätyivät Tenopir kollegoineen (2013). Tieteelliseltä tiedonlähteeltä vaaditaan edelleen luotettavuutta ja uskottavuutta, joita ei ehkä koeta sosiaalisen median ominaisuuksiksi.

Nicholasin ja muiden (2017) tutkimuksessa ilmeni eroja eri maiden tutkijoiden välillä. Esimerkiksi Kiinassa, jossa sosiaalinen media on osittain estettyä, tieteellisiä maksumuurin takana olevia artikkeleita myydään internetin kauppapaikoilla (Nicholas ym., 2017). Heidän tutkimuksensa osallistujista yksikään ei kuitenkaan kertonut käyttävänsä tätä mahdollisuutta tiedonhakuun. Google Scholar osoittautui myös Kiinassa, kuten muuallakin maailmassa, keskeisimmäksi hakuvälineeksi tieteellisen tiedon tarpeisiin informaatioympäristön rajoituksista huolimatta. Hausteinin ja muiden (2014) tutkimuksen mukaan Mendeley koettiin enemmän viittaustyökaluksi sekä tutkijoita yhdistäväksi työkaluksi, kun taas CiteULikea käytettiin enemmän puhtaasti tieteellisen kirjallisuuden hakemisen välineenä.

Maksumuuri on yksi määrittävä tekijä sosiaalisen median käyttämisessä tiedonhaussa, toinen on vaivattomuus: vaikka käyttäjillä olisi pääsy kirjaston tarjoamiin maksullisiin tietokantoihin, saatetaan kuitenkin käyttää avoimia julkaisuarkistoja, ja jopa piraattitietokantoja kuten SciHubia, puhtaasti mukavuussyistä: hakijat halusivat yhden portin kautta pääsyn kaikkeen tietoon (Bohannon, 
2016).

Aiemman tutkimuksen perusteella näyttäisi siltä, että tieteellisten artikkelien tiedonhakuun käytetään Google Scholaria, mutta muilla sosiaalisen median välineillä on oma roolinsa myös tiedonhaussa. Perinteiset kahvipöytäkeskusteluissa ja työpaikan käytävillä käydyt tutkimustyöhön liittyvät tiedontarpeet ovat osittain siirtyneet sosiaaliseen mediaan. van Noorden (2014) mainitsee esimerkkitapauksena menetelmällisen eli proseduraalisen tiedonhaun, jota tutkijat hyödyntävät kysymällä suoraan sosiaalisen median verkostoista.

\section{Sosiaalinen media eri tieteenaloilla}

On yleisesti tiedossa, että tieteenalat eroavat merkitsevästi toisistaan viestintäkäytännöiltään (esim. Piro, Aksnes, \& Rørstad, 2013). Myös sosiaalisen median käytössä on havaittu eroja tieteenalojen välillä (esim. Ortega, 2015; Almousa, 2011; Jeng ym., 2015; Tenopir ym., 2013; Thelwall \& Kousha, 2014).

Ortega (2015) tutki tieteenalaeroja tutkijoiden Google Scholar, Academia.edu-, ResearchGate- ja Mendeley profiilien määrässä ja aktiivisuudessa. Tutkimuksessa analysoitiin yli 6000 profiilia. Tutkituista palveluista tutkimukseen osallistuneilla tutkijoilla oli useimmiten profiili ResearchGate-palvelussa. Sosiaalisen median palveluihin osallistuminen oli yleisintä humanistisilla ja yhteiskuntatieteellisillä aloilla sekä luonnontieteissä. Academia.edu oli selvästi suositumpi humanistisilla ja yhteiskuntatieteellisillä aloilla, kun taas ResearchGate oli suosituin biolääketieteen aloilla.

Jeng ja kumppanit (2015) havaitsivat, että Mendeleyn ryhmissä tietotekniikka ja informaatiotieteet, yhteiskuntatieteet, kasvatustieteet, psykologia ja biolääketiede ovat suosituimpia. Mendeleyn käyttäjille tehdystä kyselytutkimuksesta selvisi, että biolääketieteen tutkijat olivat perustaneet tilin Mendeleyihin keskimäärin muita aiemmin. Tutkimus antoi viitteitä myös siitä, että Mendeley on suosituin uransa alkuvaiheessa olevien tutkijoiden keskuudessa.

Tenopirin ja kumppaneiden tutkimuksessa (Tenopir ym., 2013) selvisi, että humanistit ja lääketieteilijät lukevat muiden alojen edustajia useammin blogeja. Yhteiskuntatieteiden ja humanististen alojen edustajat seurasivat yleisesti ottaen enemmän sosiaalisen median työkaluja. Lääketieteilijät käyttivät taas muita useammin artikkeleiden kommentointimahdollisuutta. Tutkimuksen mukaan tutkijan ikä vaikuttaa myös jossain määrin sosiaalisen median käyttöön. Nuoremmat tutkijat käyttivät useammin blogeja, uutissyötteitä ja -seurantaa ja Twitteriä. Muihin sosiaalisen median palveluiden käyttöön tutkijan iällä ei kuitenkaan ollut vaikutusta. Tutkijat, jotka käyttivät yli puolet työajastaan opetukseen olivat aktiivisempia sosiaalisen median käyttäjiä verrattuna tutkijoihin, jotka käyttivät yli 50 \% työajastaan tutkimukseen. 


\section{Tutkimusaineisto- ja menetelmä}

Tutkimusaineisto kerättiin elektronisella kyselylomakkeella. Kysely oli osa Carol Tenopirin ja Donald W. Kingin Yhdysvalloissa 1977 aloittamaa kyselytutkimusten sarjaa, jolla on seurattu tutkijoiden lukemisen käytäntöjä ja niissä tapahtuvia muutoksia. Yksi sarjan kyselytutkimuksista toteutettiin aiemmin Suomessa vuonna 2006 (Tenopir, Wilson, Vakkari, Talja, \& King, 2010). Nyt käsillä oleva, Suomessa vuonna 2016 toteutettu kyselytutkimus piti uutena elementtinä sisällään osion, jossa kysymykset kohdistuivat tutkijoiden sosiaalisen median käyttöön. Tavoitteena oli selvittää sosiaalisen median käytön yleisyyttä ja käyttötapoja tutkimustyössä. Elektroninen kyselylomake lähetettiin Suomessa työskenteleville tutkijoille loka-marraskuussa 2016. Kyselylomaketta levitettiin tutkijoille FinELib-konsortion jäsenkirjastojen kautta. Kirjastoja pyydettiin lähettämään kyselyn saatekirje sekä linkki kyselylomakkeeseen organisaatiossaan työskenteleville tutkijoille sähköpostitse. Vastauksia kyselyyn saatiin yhteensä 528 , mutta vastauksien määrä vaihtelee kysymysten välillä, sillä vastaajat saivat vastata valitsemiinsa kysymyksiin.

\begin{tabular}{lrrrr}
\hline Tieteenalaryhmä & Tutkijoiden määrä & $\%$ & Kyselyyn vastanneet & $\%$ \\
\hline Luonnontieteet & 6729 & 26,5 & 154 & 29,5 \\
Teknilliset tieteet & 5358 & 21,1 & 80 & 15,3 \\
Lääketieteet & 3816 & 15,0 & 90 & 17,2 \\
Yhteiskuntatieteet & 6489 & 25,5 & 158 & 30,3 \\
Humanistiset tieteet & 2655 & 10,4 & 40 & 7,7 \\
\hline Yhteensä & 25428 & & 522 & \\
\hline
\end{tabular}

Taulukko 1: Aineiston edustavuus tieteenalaryhmien näkökulmasta

\begin{tabular}{llll}
\hline Ikäryhmä & $\%$ & Asema & $\%$ \\
\hline $21-30$ & 15 & Professori/johtaja & 24 \\
$31-40$ & 28 & Tutkijatohtori & 16 \\
$41-50$ & 24 & Väitöskirjatutkija & 21 \\
$51-60$ & 23 & Lehtori & 21 \\
$61-$ & 11 & Tutkija & 18 \\
\hline Yhteensä & $100(\mathrm{n}=528)$ & & $100(\mathrm{n}=526)$ \\
\hline
\end{tabular}

Taulukko 2: Vastaajien ikäjakauma ja jakauma aseman mukaan

Kyselyssä vastaajat valitsivat edustamansa tieteenalan 13 eri tieteenalaa sisältävästi listasta. Analyysia varten näistä muodostettiin viisi tieteenalaryhmää. Vastaajien tieteenalajakauma vastaa melko hyvin tutkijoiden todellista tieteenalajakaumaa Suomessa (ks. taulukko 1). Taulukon 1 tiedot 
on kerätty Vipunen-järjestelmästä 25.5.2017. Humanistit ja teknisten alojen edustajat ovat hieman aliedustettuina otoksessa. Vastaajat työskentelevät suomalaisissa yliopistoissa, tutkimuslaitoksissa ja ammattikorkeakouluissa. Valtion tutkimuslaitoksissa työskentelevät tutkijat ovat hieman yliedustettuina otoksessa. Voidaan kuitenkin sanoa, että vaikka kyselyn vastausprosentti on melko alhainen (koko populaatiosta 2,1\%), aineistossa eri tieteenalat ja tutkimussektorit ovat tasaisesti edustettuina. Täsmällistä vastausprosenttia ei voida laskea, sillä ei ole tiedossa kuinka suuren osan tutkijoista kysely todellisuudessa tavoitti.

Vastaajista neljännes edustaa professoreja ja johtajia, viidennes on väitöskirjatutkijoita ja viidennes lehtoreita. Loput vastaajat edustavat muita tutkijoita (18\%) tutkijatohtoreita (16\%) ja projektijohtajia/johtajia (9\%). Vastaajien ikäjakauma on melko tasainen (ks. taulukko 2).

Kysely koostui 51 kysymyksestä, joista tässä artikkelissa käsitellään niitä, jotka liittyivät sosiaalisen median käyttöön tutkijan työssä. Kysymykset ovat:

1. Miten tärkeänä pidät sosiaalisen median sisältöjen lukemista työssäsi?

2. Miten tärkeiksi koet seuraavat sosiaalisen median palvelut/välineet työssäsi?

3. Viimeisen artikkelin lukukokemus:

a. Miten sait tiedon artikkelista?

b. Miten sait artikkelin käsiisi?

c. Jaoitko viimeksi lukemasi artikkelin tai sen herättämät ajatukset sosiaalisessa mediassa?

4. Viimeisen muun julkaisun lukukokemus:

d. Miten sain tiedon julkaisusta?

e. Miten sait julkaisun käsiisi?

f. Jaoitko viimeksi lukemasi julkaisun tai sen herättämät ajatukset sosiaalisessa mediassa?

5. Miten tärkeänä pidät teknistä mahdollisuutta elektronisessa julkaisussa jakaa lukemaasi sisältöä kollegoillesi?

6. Miten tieteellisen kirjallisuuden lukeminen tai luetun jakaminen on osaltasi muuttunut viime vuosien aikana ja miten uskot sen muuttuvan seuraavien vuosien aikana? 
Kyselyn ensimmäiset viisi kysymystä olivat monivalintakysymyksiä. Aineistoa analysoitiin SPSS-ohjelmiston avulla jakaumia, keskiarvoja ja ristiintaulukointeja hyödyntäen. Tilastollisista testeistä käytetään keskiarvojen vertailuun varianssianalyysiä (ANOVA). Kuudes, lukemisessa tapahtunutta muutosta käsittelevä kysymys oli avoin kysymys, jossa vastaajat saivat omin sanoin kuvailla havaitsemiaan muutoksia. Vastauksia kysymykseen tuli yhteensä 235, joista poimittiin vastaukset joissa mainittiin sosiaalinen media $(n=31)$. Vastaukset luokiteltiin sisällön erittelyn keinoin viiteen luokkaan, jotka on lueteltu taulukossa 3. Avovastauksista poimitaan sitaatteja, joilla selitetään ja avataan kvantitatiivisia tuloksia (kysymykset 1-5).

\begin{tabular}{lll}
\hline & Lkm & $\%$ \\
\hline Tiedonhankinta & 9 & 29 \\
Tiedon jakaminen & 8 & 26 \\
Lukeminen ja viittaaminen & 6 & 19 \\
En käytä/ei oleellista & 6 & 19 \\
Muut & 2 & 6 \\
\hline Yhteensä & 31 & 100 \\
\hline
\end{tabular}

Taulukko 3: Sosiaalisen median käyttöä koskevien avovastauksien luokittelu

\section{Tulokset}

Tulosluku koostuu kolmesta eri osuudesta. Ensin esitellään tulokset liittyen sosiaalisen median merkitykseen ja rooliin tutkijan työssä. Toisessa osuudessa käsitellään sosiaalisen median osuutta tutkijoiden tiedonhankinnassa. Viimeinen osuus käsittelee sosiaalista mediaa ja luetun jakamista.

\section{Sosiaalisen median merkitys}

Kyselyssä vastaajia pyydettiin arvioimaan eri julkaisumuotojen lukemisen tärkeyttä työssään asteikolla 1-5, jossa 1 oli "välttämätöntä" ja 5 "ei tärkeää". Ainoastaan noin $2 \%$ vastaajista arvioi sosiaalisen median lukemisen välttämättömäksi työnsä kannalta (Kuva 1). Kuitenkin suurin osa (65,9 \%) vastaajista piti sosiaalisen median seuraamista vähintään jokseenkin tärkeänä. Verrattuna esimerkiksi perinteisiin julkaisuihin, kuten tieteellisiin lehtiin ja sanomalehtiin, sosiaalisen median lukeminen koettiin huomattavasti vähemmän tärkeäksi. Esimerkiksi 73 \% vastaajista piti tieteellisten lehtien ja noin $10 \%$ sanomalehtien lukemista työnsä kannalta välttämättömänä. 


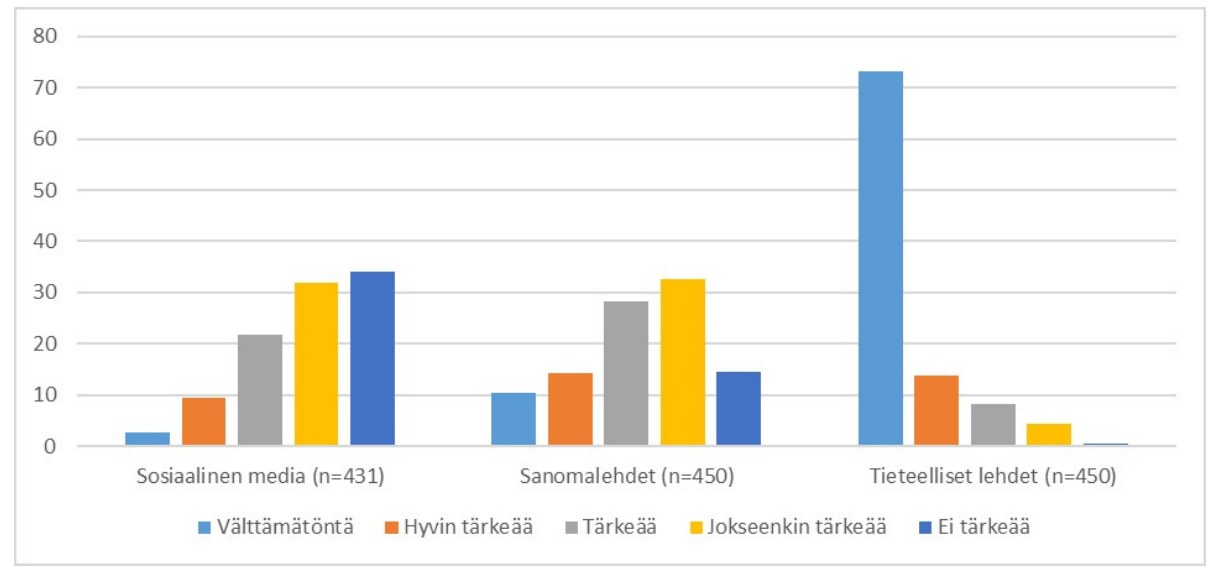

Kuva 1: Sosiaalisen median, sanomalehtien ja tieteellisten lehtien lukemisen merkitys

Sosiaalisen median lukemisen merkitys eroaa tieteenalojen välillä (keskiarvot eroavat tieteenalojen välillä tilastollisesti merkitsevästi toisistaan ANOVA $\mathrm{F}=5,901, \mathrm{chi}^{2}=, 000$ ). Humanistisilla ja yhteiskuntatieteellisillä aloilla työskentelevät tutkijat pitivät sosiaalisen median sisältöjen lukemista keskimäärin tärkeämpänä työlleen verrattuna luonnon- ja lääketieteellisillä sekä teknillisillä aloilla työskenteleviin tutkijoihin. Humanistit ja yhteiskuntatieteilijät kokivat keskimäärin myös sanomalehtien lukemisen muilla tieteenaloilla työskenteleviä tutkijoita tärkeämmäksi (ANOVA F= 7,012, chi $^{2=}$,000). Tieteellisten lehtien lukeminen koettiin tärkeäksi kaikilla tieteenaloilla. Lääketieteilijät kokivat tieteellisten lehtien lukemisen kuitenkin muita tärkeämmäksi (ANOVA F=3,433, chi² $=, 009$ ). Vastaajan ammatillisella asemalla tai iällä ei ollut vaikutusta tuloksiin.

Myöskään avovastausten perusteella sosiaalinen media ei ole ainakaan tällä hetkellä korvaamassa perinteisiä julkaisufoorumeita. Osa tutkijoista koki sosiaalisen median seuraamisen häiritsevänä tekijänä työn kannalta.

Olen alkanut lukea enemmän kirjoja ja käytän enemmän aikaa lukemiseen. Samalla blogien ja lyhyiden f-book-kommentaarien lukeminen on lisääntynyt.

Saatan vähentää levotonta pläräämistä, tiedon skannailua ja f-bookin seuraamista.

Vastaajia pyydettiin myös arvioimaan erityyppisten palvelujen merkitystä työssään. Vastaajat arvioivat palvelujen tärkeyttä viisiportaisella asteikolla, jossa 1 oli välttämätön ja 5 oli ei lainkaan tärkeä. Yleisesti ottaen mitään kysytyistä 


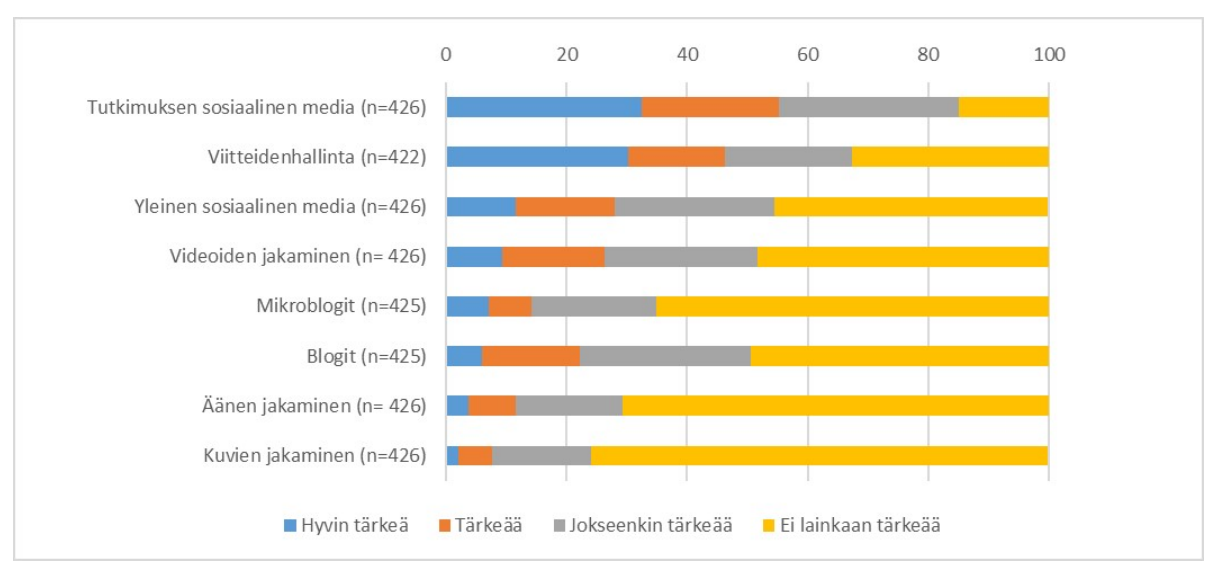

Kuva 2: Erilaisten sosiaalisen median palvelujen merkitys tutkijoiden työssä

sosiaalisen median palveluista ei pidetty erityisen tärkeinä tai ainakaan välttämättöminä tutkimustyössä (Kuva 2). Tutkimuksen sosiaalisen median palvelut (esim. ResearchGate, Academic.edu) sekä viitteidenhallintaohjelmistot (esim. Mendeley tai Zotero) arvioitiin tärkeimmiksi tutkimuksen kannalta. Lähes puolet vastaajista arvioi näiden olevan vähintään tärkeitä. Yleisten sosiaalisen median palvelujen (esim. Facebook, blogit, Twitter, Instagram, YouTube, podcastit) roolia ei nähty yhtä merkitykselliseksi tutkijan työssä. Alle 30 \% vastaajista piti Facebookia tai vastaavaa sosiaalisen median palvelua tai videoiden jakamiseen tarkoitettu palvelua, kuten YouTubea vähintään tärkeänä. Noin 20\% koki blogit ja $15 \%$ mikroblogit, kuten Twitterin tärkeäksi tai erittäin tärkeäksi ja noin $10 \%$ kuvien (esim. Instagram) ja puheen ja äänen (podcastit) jakamiseen tarkoitetut palvelut vähintään tärkeiksi.

Tieteenalojen välillä on joitakin tilastollisia eroja myös eri palvelujen koetussa merkityksessä. Lääketieteiden edustajat arvioivat viitteidenhallintaohjelmien merkityksen muiden tieteenalojen edustajia keskimäärin korkeammaksi (ANOVA $\mathrm{F}=8,654, \mathrm{chi}^{2}=, 000$ ). Luonnontieteiden, lääketieteiden ja yhteiskuntatieteiden edustajat arvioivat akateemiset sosiaalisen median palvelut keskimäärin tärkeämmiksi verrattuna teknillisten ja humanististen alojen edustajiin (ANO$\left.\mathrm{VA} \mathrm{F}=3,362, \mathrm{chi}^{2}=, 010\right)$. Yhteiskuntatieteiden ja humanisten alojen edustajat arvioivat taas yleiset sosiaalisen median palvelut muiden alojen edustajia keskimäärin tärkeämmiksi (ANOVA $\mathrm{F}=8,083, \mathrm{chi}^{2}=, 000$ ). Yhteiskuntatieteilijät arvioivat myös blogit keskimäärin tärkeämmäksi verrattuna muihin tieteenaloihin (ANOVA F=6,427, chi $^{2}=, 000$ ). Vastaajan ammatillisella asemalla tai iällä ei ollut vaikutusta tuloksiin.

Avovastauksissa vastaajat mainitsivat nimeltä palveluista erityisesti 
ResearchGaten (7), Mendeleyn (6), Twitterin (4), Academia.edun (4) ja Facebookin (2). Useammassa avovastauksessa nousi esiin Mendeleyn rooli lukemisessa, viittaamisessa ja muistiinpanojen tekemisessä. Yksi tutkijoista kirjoitti:

Lukemisen osalta muutos on ollut entistä enemmän Mendeleyn suuntaan, josta voin helposti linkittää lukemani kirjoittamaani.

Myös toinen vastaaja korosti Twitterin merkitystä:

Hoidan kahdessa isossa hankkeessa myös hankeviestintää, joten olen ottanut Twitterin työvälineekseni ja käytän sitä joka päivä, myös viikonloppuna.

Twitter ja muut sosiaalisen median palvelut koetaan hyödylliseksi, jos palvelujen kautta löytyy itselle mielekäs ja aktiivinen verkosto. Jos tämä ei toteudu, ei palvelusta ole juurikaan hyötyä aineistojen jakamisen tai löytämisen osalta. Muistiinpanojen tekemisen vaikeus on myös viime vuosiin saakka ylläpitänyt artikkeleiden tulostamista paperille. Mendeleyn kaltaiset palvelut voivat tarjota uusia ratkaisuja myös lukemiseen digitaalisessa formaatissa.

\section{Sosiaalisen median rooli tiedonhankinnassa}

Kyselyn toisessa osuudessa kysymykset kohdistuivat vastaajien viimeksi lukemaan tieteelliseen lehtiartikkeliin ja viimeksi lukemaan muuhun julkaisuun, kuten kirjaan, konferenssijulkaisuun, raporttiin, sanomalehteen jne. Luetuksi määriteltiin julkaisu, jossa lukeminen oli edennyt tiivistelmän yli itse tekstiin. Myös leipätekstin silmäily ja selailu laskettiin lukemiseksi. Aineisto sisältää yhteensä 425 tieteellisen lehtiartikkelin ja 415 muun lukukokemuksen raportoinnin. Vastaajilta kysyttiin miten he olivat saaneet tiedon viimeksi lukemastaan artikkelista/julkaisusta ja mitä kautta he olivat saaneet artikkelin/julkaisun käsiinsä.

Ensimmäisen kysymyksen osalta (tieto viimeksi luetusta artikkelista/julkaisusta) vastaukset jaoteltiin aktiiviseen tiedonhakuun ja suuntaamattomaan monitorointiin (ks. McKenzie, 2003). Aktiiviseen hakemiseen laskettiin mukaan tiedonhaku, lähdeluettelon käyttö sekä artikkelin oma tilaus. Suuntaamattomaan monitorointiin luokiteltiin julkaisun saaminen kollegalta, selailun aikana löytäminen sekä sosiaalinen media ja uutuusseuranta (journal alerts). Tyypillisimmin tutkijat saivat tiedon viimeksi lukemastaan artikkelista perinteisesti aktiivisella tiedonhaulla (Taulukko 4). Suuntamaton monitorointi oli taas tyypillisempää muiden julkaisujen hankinnassa. 


\begin{tabular}{lccc}
\hline & $\begin{array}{c}\text { Tieteellinen artikkeli } \\
(\mathrm{n}=442)\end{array}$ & Muu julkaisu (n=384) & Yhteensä $(\mathrm{n}=826)$ \\
\hline Aktiivinen tiedonhaku & 59,3 & 42,4 & 51,5 \\
Suuntamaton & 40,7 & 57,6 & 48,5 \\
monitorointi & 100 & 100 & 100 \\
\hline Yhteensä & & & \\
\hline
\end{tabular}

Taulukko 4: Tiedonhankinnan tavat eri julkaisutyypeissä (\%).

Tarkasteltaessa kaikkia vastauksia, noin $6 \%$ vastaajista sai tiedon viimeksi lukemastaan tieteellisestä artikkelista sosiaalisen median tai uutuusseurannan kautta. Jos taas tarkastellaan lähemmin suuntaamatonta monitorointia (ks. Taulukko 5), sosiaalisen median osuus on tieteellisten julkaisujen tiedonhankinnassa yleisempää (noin $17 \%$ ) kuin muiden julkaisujen tiedonhankinnassa (vain noin $5 \%$ ). Tässä kuitenkin on otettava huomioon uutuusseurannan laskeminen mukaan sosiaalisen median kanavaan.

\begin{tabular}{lccc}
\hline Hankintakanava & $\begin{array}{c}\text { Tieteellinen artikkeli } \\
(\mathrm{n}=180)\end{array}$ & Muu julkaisu $(\mathrm{n}=\mathbf{2 2 1})$ & Yhteensä $(\mathrm{n}=401)$ \\
\hline Kollegat & 46,1 & 36,2 & 40,6 \\
Selailu & 26,7 & 48,0 & 38,4 \\
Sosiaalinen media & 16,7 & 5,0 & 10,2 \\
Muu & 10,6 & 10,9 & 10,7 \\
\hline Yhteensä & 100 & 100 & 100 \\
\hline
\end{tabular}

Taulukko 5: Suuntaamattoman monitoroinnin tiedonhankinnan kanavat eri julkaisutyypeissä (\%).

Tutkijoita pyydettiin myös kertomaan, mitä kautta he saivat artikkelin ja julkaisun käsiinsä luettavaksi (kuva 3). Noin 6 \% vastaajista sai viimeksi lukemansa tieteellisen artikkelin käsiinsä sosiaalisen median kautta. Tyypillisin tapa saada artikkeli käsiin oli organisaation tilauksen kautta (49 \%). Muiden julkaisujen osalta noin 3 \% luetuista julkaisuista oli saatu käsiin sosiaalisen median kautta. Tyypillisimmin julkaisut saatiin käsiin kirjaston (27\%), oman kokoelman (21 \%) tai verkkosivujen ( $21 \%)$ kautta.

Avovastauksissa sosiaalisen median rooli tiedonhaussa tuli esiin lähinnä Google Scholarin kautta. Palvelut ovat parantaneet julkaisujen saatavuutta maksullisten aineistojen ja esimerkiksi konferenssijulkaisujen osalta.

Julkaisut löytyvät nopeammin ja helpommin Google Scholarin avulla. Lisäksi Twitterin kautta löytää jatkuvasti paljon kiinnostavaa akateemista ja ei-akateemista luettavaa. Tulevaisuudessa uskon näiden 


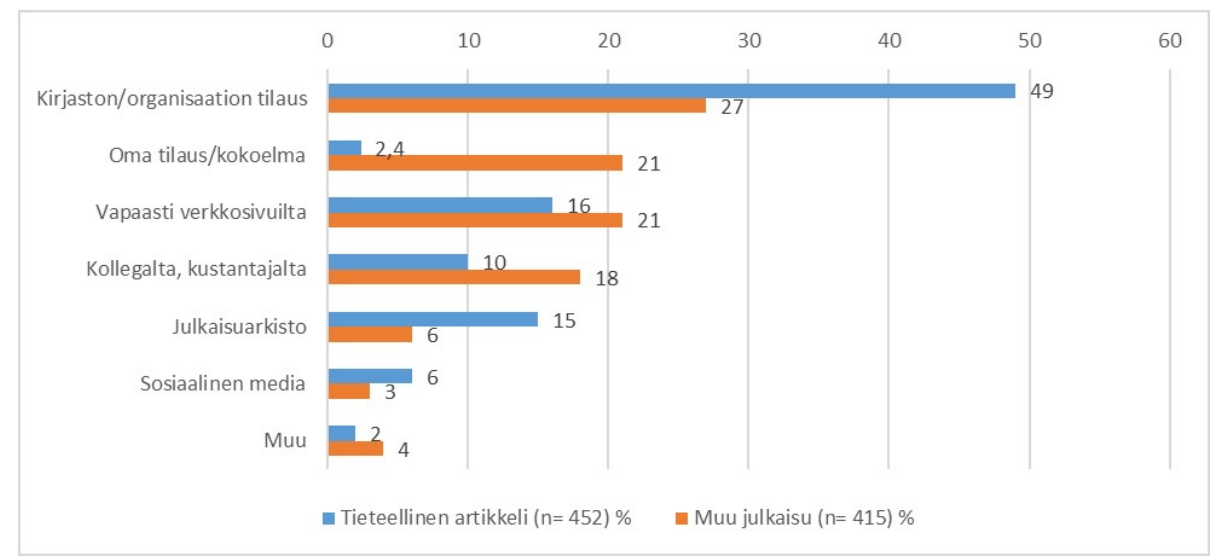

Kuva 3: Miten artikkeli/julkaisu saatiin käsille?

trendien jatkuvan ja esim. Googlen osaavan suositella minulle kiinnostavia artikkeleita paremmin ja paremmin.

ResearchGate on tuonut esim. konferenssijulkaisut helpommin saataviksi. Tulevaisuudessa toivon voivani seurata nimeäminäni aiheita riippumatta julkaisu-foorumista (yhteinen automaattinen poiminta lehdistä, uutisista, konferensseista. podeista jne.)

Tutkijat arvostavat suosittelujärjestelmiä, jotka tarjoavat lisää luettavaa. Tähän ollaan totuttu jo muissa verkkopalveluissa, kuten verkkokaupoissa. Sosiaalinen media ei niinkään toimi tiedonhaun välineenä, vaan se voi lisätä tiedonhaun serendipiteettiä ja sitä kautta voi tehdä yllättäviäkin löytöjä.

\section{Julkaisujen jakaminen sosiaalisessa mediassa}

Vastaajilta myös kysyttiin jakoivatko he viimeksi lukemansa tieteellisen artikkelin ja muun julkaisun tai luetun herättämät ajatukset sosiaalisessa mediassa. Tulosten mukaan tutkijat jakavat ainoastaan murto-osan lukemistaan julkaisuista sosiaalisessa mediassa (Taulukko 6). Suurin osa (93\%) tutkijoista ei jakanut viimeksi lukemaansa artikkelia tai sen herättämiä ajatuksia sosiaalisessa mediassa. Jakaminen oli yhtä epätodennäköistä muiden julkaisujen osalta. Vastaajan edustamalla tieteenalalla, ammatillisella asemalla tai iällä ei ollut vaikutusta tuloksiin.

Tuloksista huolimatta tutkijat pitävät tärkeinä artikkeleiden ja muiden julkaisujen jakamisen mahdollisuutta. Kyselyssä kysyttiin, miten tärkeänä tutkijat 


\begin{tabular}{lccc}
\hline & $\begin{array}{c}\text { Viimeksi luettu } \\
\text { artikkeli }(\mathrm{n}=453)\end{array}$ & $\begin{array}{c}\text { Viimeksi luettu } \\
\text { muu julkaisu } \\
(\mathrm{n}=414)\end{array}$ & Yhteensä $(\mathrm{n}=867)$ \\
\hline $\begin{array}{l}\text { Kyllä, jaoin artikkelin/julkaisun } \\
\text { Kyllä, jaoin lukemani herättämät }\end{array}$ & 2,4 & 3,1 & 2,8 \\
ajatukset & 2,2 & 2,7 & 2,4 \\
En & 92,5 & 91,5 & 92 \\
En, mutta teen niin tulevaisuudessa & 2,9 & 2,7 & 2,8 \\
\hline Yhteensä & 100 & 100 & 100 \\
\hline
\end{tabular}

Taulukko 6: Viimeksi luetun tieteellisen artikkelin ja muun julkaisun jakaminen sosiaalisessa mediassa (\%).

pitivät erilaisia e-resurssien ominaisuuksia. Kolme neljäsosaa vastaajista piti teknistä mahdollisuutta jakaa julkaisuja kollegojen kanssa vähintäänkin tärkeänä. Viidesosa vastaajista piti sitä jopa välttämättömänä. Vastaajan edustamalla tieteenalalla, ammatillisella asemalla tai iällä ei ollut vaikutusta tuloksiin.

Sosiaalisen median rooli tiedon jakamisen välineenä nousi esiin avovastauksissa.

Jaan useammin ajatuksiani lukemastani sosiaalisessa mediassa, olen myös aloittanut jakamaan kirjoitusteni draft-versioita eri portaalien kautta, jotta kaikilla olisi mahdollisuus tutustua teksteihini.

Toivon, että olisi joku hyvä tapa jakaa julkaisuja tutkimusryhmän sisällä nykyisen sähköpostilla lähettämisen sijaan. Nykyiset ohjelmistot, mm. Mendeley, ovat liian hankalia eivätkä ihmiset edelleenkään jaksa käyttää niitä.

Joskus joku pyytää artikkeli-pdf:aa ResearchGatessa tai emailitse aiempien postikorttien asemesta.

Sosiaalisessa mediassa tutkijoilla on mahdollisuus markkinoida omaa tutkimustaan toisille tutkijoille ja alan toimijoille. Epäselvää on, missä määrin tutkijat ovat ottaneet sosiaalisen median palvelut työskentelyvälineiksi esimerkiksi tutkimusryhmien sisällä.

\section{Johtopäätökset}

Tutkimuksemme tuotti uusia tuloksia tutkijoiden sosiaalisen median käytöstä. Ensimmäinen tutkimuskysymyksemme oli miten tärkeiksi tutkijat kokevat eri sosiaalisen median palvelut työssään. Yleisesti ottaen sosiaalisen median seuraamista ja lukemista ei koeta välttämättömäksi tutkijan työssä, mutta suurin 
osa kyselyyn vastaajista pitää sosiaalisen median seuraamista tärkeänä tai jokseenkin tärkeänä. Perinteiset viestintäkanavat, kuten tieteelliset lehdet ja sanomalehdet pitävät edelleen pintansa samoin kuin viisi vuotta sitten Tenopirin ja kumppaneiden (2013) tutkimuksessa. Tutkijat kokevat tieteelliset tiedonlähteet sosiaalista mediaan luotettavimmiksi ja uskottavimmiksi (Nicholas ym., 2017). Erilaisista sosiaalisen median palveluista vastaajat painottivat erityisesti tutkimukseen suunniteltuja sosiaalisen median palveluja, kuten ResearchGate ja Academia.edu palveluja sekä viitteidenhallintaan suunniteltuja palveluja. ResearchGate, Mendeley, Twitter ja Academia.edu saivat eniten mainintoja myös avovastauksissa. Nämä ovatkin tunnetuimpia palveluja myös aiempien selvitysten perusteella (Ortega, 2015). Uusia sosiaalisen median palveluja kuitenkin syntyy ja olemassa oleville palveluille keksitään uusia käyttötarkoituksia. Teknisten alustojen kehittyessä tukemaan paremmin digitaalisessa muodossa lukemista ja muistiinpanojen tekemistä sekä tiedonhaun serendipiteettiä paremmilla suosittelumenetelmillä, uusien palvelujen merkitys tulee todennäköisesti korostumaan. Tämän vuoksi tutkimusta sosiaalisen median palvelujen käytöstä tarvitaan myös tulevaisuudessa.

Tarkastelimme myös tieteenalan, ammatillisen aseman ja iän vaikutusta sosiaalisen median rooliin tutkijan työssä. Tutkimus osoitti eroja tieteenalojen välillä sosiaalisen median roolissa. Yleisesti ottaen sosiaalinen media koettiin tärkeimmäksi yhteiskuntatieteellisillä ja humanistisilla aloilla. Lääketieteissä viitteidenhallintaohjelmat arvioitiin muita aloja tärkeämmäksi. Tieteenalaerojen osalta tulokset tukevat aiempien tutkimusten löydöksiä (esim. Ortega, 2015). Vaikuttaa siltä, että sosiaalinen median käyttö on yhteydessä tieteenalojen julkaisukäytäntöihin, jotka eroavat merkittävästi niin sanottujen kovien ja pehmeiden alojen välillä (esim. Piro ym., 2013). Yhteiskuntatieteissä ja humanistisilla aloilla ammatillisten yleisöjen ja suuren yleisön merkitys on suurempi verrattuna koviin aloihin, kuten luonnontieteisiin (Puuska \& Miettinen, 2008). Tämän vuoksi näillä aloilla myös sosiaalinen media, jonka avulla voidaan tavoittaa helpommin tiedeyhteisön ulkopuolisia yleisöjä, saatetaan kokea tärkeämmäksi. Tieteenalojen välillä ei löydetty eroja sosiaalisen median käytöstä tiedonhankinnassa tai aineistojen jakamisessa. Tutkijan ammatillisella asemalla tai iällä ei ollut vaikutusta tuloksiin.

Kolmanneksi kysyimme mikä on sosiaalisen median asema tutkijoiden tiedonhankinnassa. Jaoimme tiedonhankintatavat aktiiviseen tiedonhakuun ja suuntaamattomaan monitorointiin McKenzien (2003) jaottelua mukaillen. Sosiaalinen media sijoittui suuntaamattomaan monitorointiin yhdessä esimerkiksi selailun ja kollegan kautta saadun tiedon kanssa. Tulokset osoittavat, että sosiaalisella medialla on vähäinen rooli tutkijoiden tiedonhankinnassa. Vain murto-osa luetuista tieteellisistä artikkeleista ja muista julkaisuista 
löydetään ja saadaan käsiin sosiaalisen median kautta. Tyypillisimmin tutkijat saivat tiedon viimeksi lukemastaan artikkelista perinteisesti aktiivisella tiedonhaulla. Sosiaalinen media on kuitenkin kasvattanut aineistojen saatavuutta ja esimerkiksi artikkelit, joihin tutkijalla ei muuten olisi pääsyä, voivat hyvällä todennäköisyydellä löytyä akateemisista sosiaalisen median palveluista. Suomessa sosiaalisen median rooli tieteellisen tiedon lähteenä saattaa kuitenkin olla pieni, sillä suomalaisissa tutkimusorganisaatioissa tiedejulkaisujen saatavuus on kansainvälisesti katsottuna hyvä, koska hankinnat hoidetaan keskitetysti FinELib-konsortion kautta. Maissa, joissa aineistojen saatavuus ei ole yhtä hyvä, sosiaalisen median rooli tiedonhankinnassa on todennäköisesti suurempi (Nicholas ym., 2017). Aiheesta on kuitenkin toistaiseksi vähän tutkimusta (esim. van Noorden, 2014) ja tulevassa tutkimuksessa olisikin kiinnostava selvittää yksityiskohtaisemmin sosiaalisen median käyttöä tiedonhankinnassa.

Tarkastelimme myös missä määrin tutkijat jakavat lukemiaan julkaisuja sosiaalisessa mediassa. Tulokset osoittavat, että luetun julkaisun tai sen herättämien ajatusten jakaminen sosiaalisessa mediassa on edelleen melko vähäistä (myös Tenopir ym., 2013, 2017). Kuitenkin suurin osa tutkijoista piti teknistä mahdollisuutta jakaa julkaisuja kollegojen kanssa vähintään tärkeänä. Viidesosa vastaajista piti sitä jopa välttämättömänä. Täytyy kuitenkin muistaa, että aineistomme ulkopuolella jäävät tutkijoiden omien artikkeleiden jakamisen käytännöt sosiaalisessa mediassa. Onkin todennäköistä, että tutkijat jakavat pääosin omia julkaisujaan. Itseviittausten käsittely ja aineistojen manipulointi onkin yksi altmetriikan ongelmista (Bornmann, 2014). Tutkijat, tutkimusorganisaatiot ja julkaisijat voivat vaikuttaa merkittävästi julkaisujen näkyvyyteen sosiaalisessa mediassa esimerkiksi jakamalla julkaisuja automaattisesti eri kanaviin.

Vaikuttaa siltä, että sosiaalinen media ei ole toistaiseksi tehnyt läpimurtoa akateemisessa maailmassa. Jatkossa olisikin kiinnostava selvittää syitä tähän. Koetaanko sosiaalinen media liian henkilökohtaiseksi, eikö sille löydy aikaa, eivätkö tarjolla olevat palvelut toimi tai sovellu tutkimusprosessiin? On kuitenkin mahdollista, että sosiaalisen median rooli tutkijan työssä on suurempi mitä tulokset antavat ymmärtää. Todennäköisesti tutkijat saavat sosiaalisen median kautta lukuvinkkejä enemmän kuin huomaavatkaan. Sosiaalisen median päivitysvirta on jatkuva, jolloin lukijan voi olla mahdotonta rekisteröidä aktiivisesti kaikkea lukemaansa. Sosiaalinen media koskettaa lähes jokaista elämän osaaluetta, eikä selvää rajaa vapaa-ajan ja työajan välille voida aina vetää vaikka tutkija siihen tietoisesti pyrkisikin vaan ne kietoutuvat osittain toisiinsa, (ks. Jeng ym., 2015). Sosiaalinen media laajentaa entisestään tiedon saatavuutta ja voi parhaimmillaan toimia vilkkaana keskustelufoorumina, joka ei tunne maantieteellisiä rajoja. Sosiaalinen media tarjoaa myös tutkimuksellisesti uusia 
mahdollisuuksia esimerkiksi tutkimusaineistojen keräämisessä. Tutkija ei voi kuitenkaan turvautua sosiaaliseen mediaan esimerkiksi tieteellisessä kirjoitusprosessissa vaan silloin on hakeuduttava alkuperäisten lähteiden äärelle.

Tämän artikkelin kirjoittamista on osittain rahoitettu Suomen Akatemia hankkeesta numero 310278 .

\section{Lähteet}

Almousa, O. (2011). Users' classification and usage-pattern identification in academic social networks. Teoksessa 2011 IEEE Jordan Conference on Applied Electrical Engineering and Computing Technologies (AEECT) (ss. 1-6). IEEE. https://doi.org/10.1109/AEECT. 2011.6132525

Bohannon, J. (2016). Who's downloading pirated papers? Everyone. Science. https://doi.org/10. $1126 /$ science. aaf5664

Bornmann, L. (2014). Do altmetrics point to the broader impact of research? An overview of benefits and disadvantages of altmetrics. Journal of Informetrics, 8(4), 895-903. https://doi. org $/ 10.1016 / j . j o i .2014 .09 .005$

Boyd, D. M., \& Ellison, N. B. (2007). Social Network Sites: Definition, History, and Scholarship. Journal of Computer-Mediated Communication, 13(1), 210-230. https://doi.org/10.1111/j. 1083-6101.2007.00393.x

Eysenbach, G. (2011). Can Tweets Predict Citations? Metrics of Social Impact Based on Twitter and Correlation with Traditional Metrics of Scientific Impact. Journal of Medical Internet Research, 13(4). https://doi.org/10.2196/jmir.2012

Greifeneder, E., Pontis, S., Blandford, A., Attalla, H., Neal, D., \& Schlebbe, K. (2017). Researchers' attitudes towards the use of social networking sites. Journal of Documentation, 74(1), 119-136. https://doi.org/10.1108/JD-04-2017-0051

Gruzd, A. (2012). Non-academic and academic social networking sites for online scholarly communities. Teoksessa D. R. Neal (toim.), Social Media for Academics: A Practical Guide (ss. 21-37). Chandos. http://doi.org/10.1016/B978-1-84334-681-4.50002-5

Gruzd, A., \& Goertzen, M. (2013). Wired Academia: Why Social Science Scholars Are Using Social Media. Teoksessa 2013 46th Hawaii International Conference on System Sciences (ss. 3332-3341). https://doi.org/10.1109/HICSS.2013.614

Gu, F., \& Widén-Wulff, G. (2011). Scholarly communication and possible changes in the context of social media: A Finnish case study. The Electronic Library, 29(6), 762-776. https://doi. org/10.1108/02640471111187999

Haustein, S., Peters, I., Bar-Ilan, J., Priem, J., Shema, H., \& Terliesner, J. (2014). Coverage and adoption of altmetrics sources in the bibliometric community. Scientometrics, 101(2), 11451163. https://doi.org/10.1007/s11192-013-1221-3

Jeng, W., He, D., \& Jiang, J. (2015). User participation in an academic social networking service: A survey of open group users on Mendeley. Journal of the Association for Information Science and Technology, 66(5), 890-904. https://doi.org/10.1002/asi.23225

Jordan, K. (2014). Academics and their online networks: Exploring the role of academic social networking sites. First Monday, 19(11). https://doi.org/10.5210/fm.v19i11.4937

Katvala, M., \& Kortelainen, T. (2012). Huomiodata ja sosiaalisen median välineet tieteellisissä lehdissa. Informaatiotutkimus, 31(3). https://journal.fi/inf/article/view/7146

Krause, J. (2012). Tracking references with social media tools: organizing what you've read or want to read. Teoksessa D. R. Neal (toim.), Social Media for Academics: A Practical Guide (ss. 85-104). Chandos. https://doi.org/10.1016/B978-1-84334-681-4.50005-0 
Mas-Bleda, A., Thelwall, M., Kousha, K., \& Aguillo, I. F. (2014). Do highly cited researchers successfully use the social web? Scientometrics, 101(1), 337-356. https://doi.org/10.1007/ s11192-014-1345-0

McKenzie, P. J. (2003). A model of information practices in accounts of everyday-life information seeking. Journal of Documentation, 59(1), 19-40. https://doi.org/10.1108/ 00220410310457993

Nicholas, D., Boukacem-Zeghmouri, C., Rodríguez-Bravo, B., Xu, J., Watkinson, A., Abrizah, A., ... Świgoń, M. (2017). Where and how early career researchers find scholarly information. Learned Publishing, 3o(1), 19-29. https://doi.org/10.1002/leap.1087

Nicholas, D., Herman, E., Jamali, H., Rodríguez-Bravo, B., Boukacem-Zeghmouri, C., Dobrowolski, T., \& Pouchot, S. (2015). New ways of building, showcasing, and measuring scholarly reputation. Learned Publishing, 28(3), 169-183. https://doi.org/10.1087/20150303

Ortega, J. L. (2015). Disciplinary differences in the use of academic social networking sites. Online Information Review, 39(4), 520-536. https://doi.org/10.1108/0IR-03-2015-0093

Piro, F. N., Aksnes, D. W., \& Rørstad, K. (2013). A macro analysis of productivity differences across fields: Challenges in the measurement of scientific publishing. Journal of the American Society for Information Science and Technology, 64(2), 307-320. https://doi.org/10.1002/asi.22746

Puuska, H.-M., \& Miettinen, M. (2008). Julkaisukäytännöt eri tieteenaloilla. opetus- ja kulttuuriministeriö. http://urn.fi/URN: ISBN: 978-952-485-566-2

Sugimoto, C. R., Work, S., Larivière, V., \& Haustein, S. (2017). Scholarly use of social media and altmetrics: A review of the literature. Journal of the Association for Information Science and Technology, 68(9), 2037-2062. https://doi.org/10.1002/asi.23833

Tenopir, C., Allard, S., Christian, L., Anderson, R., Ali-Saleh, S., Nicholas, D., ... Woodward, H. (2017). No scholar is an island: The impact of sharing in the work life of scholars. Learned Publishing, 30(1), 5-17. https://doi.org/10.1002/leap.1090

Tenopir, C., Volentine, R., \& King, D. W. (2013). Social media and scholarly reading. Online Information Review, 37(2), 193-216. https://doi.org/10.1108/0IR-04-2012-0062

Tenopir, C., Wilson, C. S., Vakkari, P., Talja, S., \& King, D. W. (2010). Cross Country Comparison of Scholarly E-Reading Patterns in Australia, Finland, and the United States. Australian Academic \& Research Libraries, 41(1), 26-41. https://doi.org/10.1080/00048623.2010.10721432

Thelwall, M. (2018). Early Mendeley readers correlate with later citation counts. Scientometrics, 115(3), 1231-1240. https://doi.org/10.1007/s11192-018-2715-9

Thelwall, M., \& Kousha, K. (2014). Academia.edu: Social network or Academic Network? Journal of the Association for Information Science and Technology, 65(4), 721-731. https://doi .org/ $10.1002 /$ asi. 23038

van Noorden, R. (2014). Online collaboration: Scientists and the social network. Nature News, 512(7513), 126-129. https://doi.org/10.1038/512126a

Weller, K. (2015). Social Media and Altmetrics: An Overview of Current Alternative Approaches to Measuring Scholarly Impact. Teoksessa I. M. Welpe, J. Wollersheim, S. Ringelhan, \& M. Osterloh (toim.), Incentives and Performance: Governance of Research Organizations (ss. 261276). Cham: Springer International Publishing. https://doi .org/10.1007/978-3-319-097855_16 